\section{Original Research}

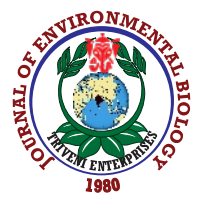

DOI : http://doi.org/10.22438/jeb/41/2(SI)/JEB-05
Journal Home page : www.jeb.co.in $\star$ E-mail : editor@jeb.co.in

\section{Journal of Environmental Biology}

p-ISSN: 0254-8704 e-ISSN: 2394-0379 CODEN: JEBIDP
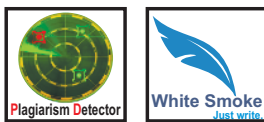

\title{
Metals distribution in soil contaminated by gold and copper mining in Georgia
}

\author{
M. Avkopashvili ${ }^{1 *}$, A. Gongadze ${ }^{2}$, G. Avkopashvili ${ }^{2}$ L. Matchavariani ${ }^{1}$, L. Asanidze ${ }^{3}$ and L. Lagidze ${ }^{1}$ \\ 'Department of Geography, Faculty of Exact and Natural Sciences, Ivane Javakhishvili Tbilisi State University, Tbilisi, 0179, Georgia \\ ${ }^{2}$ Applied Research Center, Elephter Andronikashvili Institute of Physics, Ivane Javakhishvili Tbilisi State University, Tbilisi, 0177, Georgia \\ ${ }^{3}$ Vakhushti Bagrationi Institute of Geography, Ivane Javakhishvili Tbilisi State University, Tbilisi, 0177, Georgia \\ *Corresponding Author Email : marika.avkopashvili.1@iliauni.edu.ge
}

Aim: The study aimed analyzed of heavy metal distribution in soils and their contamination in the metallogenic province of the Lesser Caucasus (Kvemo Kartli region), due to mining of gold and copper ores.

Methodology: Samples were taken from the soil and analyzed using ICP-MC and AAS. Special formula was developed to reflect the relative distribution of the element in the soil profile.

Results: The research showed that intensive mining has been leading to increase scale and indicator of the contamination. Within the long period of time weather (wind, rain, snow) pollution was being spread over the far distances. Formation of molecular complexes in the soil can reduce certain metals.

Interpretation: The research revealed that atomic mass of elements can influence their movement in air, i.e., lighter the atomic mass of the element farthest its

Key words: Gold mines, Georgia, Heavy metals, Open pit, Soil contamination

\section{Abstract}

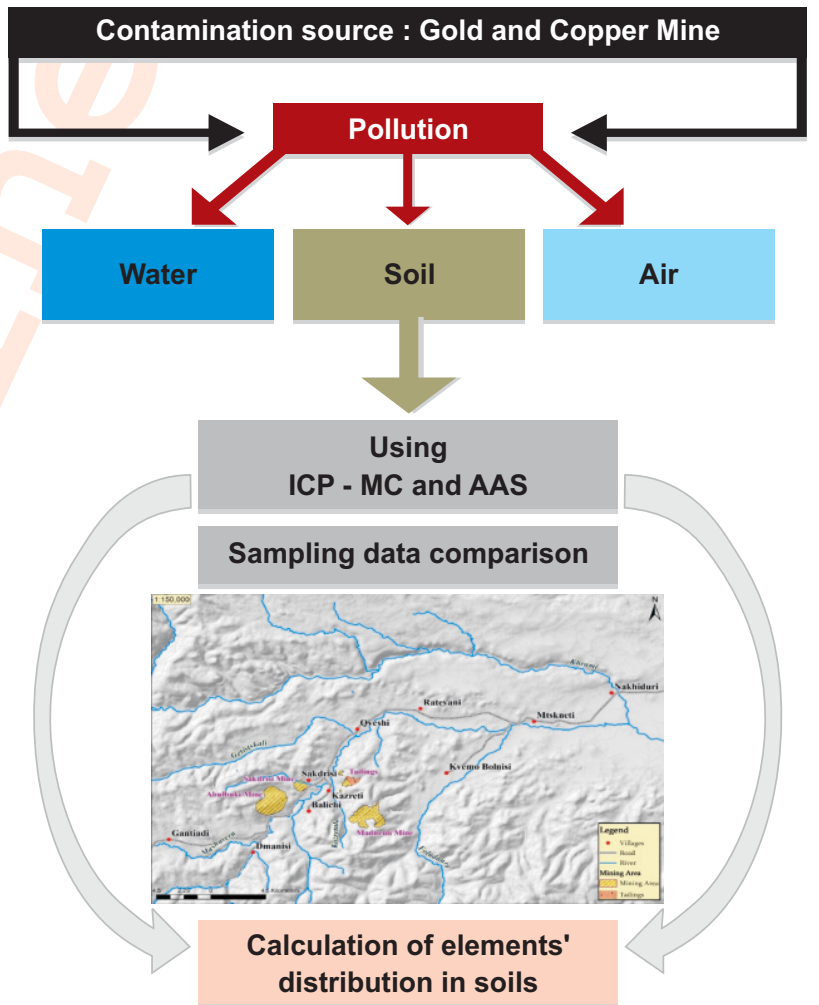

How to cite : Avkopashvili, M., A. Gongadze, G. Avkopashvili, L. Matchavariani, L. Asanidze and L. Lagidze: Metals distribution in soil contaminated by gold and copper mining in Georgia. J. Environ. Biol., 41, 310-317 (2020). 


\section{Introduction}

Currently, the influence of industrial wastes on the environment, especially on water and soil, where heavy metals are accumulated, is increasing significantly (Matchavariani et al., 2012; Sherameti et al., 2010).

Water and soil pollution by heavy metals is a global problem throughout the world. Through precipitation and wind, chemical elements emitted in the air can be spread out to long distances, which increase the risk of ingression into the human body. Heavy metals can change the structure and fertility of soils, destroy bio-ecological varieties, including local plant formations (Baycu et al., 2015; Conesa et al., 2006). The possible change in the absorption and accumulation characteristics of heavy metals by plants depends on the concentration of the element, distribution, soil properties, temperature and types of plants (Khatiashvili et al., 2015; Prasad et al., 2008; Dixit et al., 2015). The existence of a small amount of heavy metals in the soil does not harm plants, although over time they accumulate in the soil, hence the ability of their absorption by plants increases (Alkoeta et al., 2004; Khan et al., 2008; Prasad et al., 2003; Prasad et al., 2008).

Soil is the most specific and complex component of ecosystem. (Bargali et al., 2018; Bargali et al., 2019). In the case of water and air, while removing toxic substances, they easily restore their primary state. As for soil, everything is more complicated. If it is contaminated, the centennial equilibrium is disturbed, its normal functioning decreases drastically, and restoration of primary state requires a considerably longer period.

For millennia, the extraction of various polymetallic resources in Georgia has caused number of environmental problems (Felix-Henningsen et al., 2007; Placek et al., 2016). This study is concerned with RMG Gold and Copper Mine which has been functioning since the 70 s of last century in the region of Kvemo Kartli (Georgia). The company uses an open-pit mining method that has been polluting the region with a variety of toxic metals (Avkopashvili et al., 2017).

Mining is significant for the economic development of any country, but its harmful impact on the environment must be considered. Open pit mining is dangerous for the ecosystem, when environmental issues are neglected. Because of intensive production, a large number of toxic elements are released in the air, which pose negative effects on the ecosystem. Through precipitation, heavy metals accumulate in the soil and contaminates.

Similar activities are been carried out in the metallogenic province of the Lesser Caucasus in the region of Kvemo Kartli, where Gold and Copper ores are mined and are polluting the region.
Thus, the aim of this study was to analyze the distribution of heavy metals in the soils and their contamination during three years. To illustrate different distribution of metals in the soil profile, a dimensionless parameter was introduced to characterize the relative distribution of a particular chemical element in the soil profile. The numerical value of this parameter depends both on the method of contamination and also on the type of soil (Avkopashvili et al., 2017).

\section{Materials and Methods}

The study area represents the metallogenic province of the Lesser Caucasus in the region of Kvemo Kartli - Bolnisi municipality (Fig. 1). This is one of the most important mining regions of Georgia, represented in the valley of the Mashavera River. RMG (Rich Metals Group) Gold and Copper mine is located in Kazreti, approximately $80 \mathrm{~km}$ southwest of Tbilisi, on the bank of Mashavera and Kazretula rivers. It is one of the largest enterprises in Georgia and Caucasus region. It has been functioning since 1970. The main part of the region is being used for agricultural purposes. The presence and distribution of some heavy metals in soils in the surrounding area is the result of the influence of open quarries. Wastewater from the mining and processing plant is released into the Kazretula River, which flows into the river Mashavera. Eventually, Mashavera is used for irrigation.

Geologically, the area is represented mainly by quaternary sediments, limestones, sandstones and magmatic formations of the Cretaceous and Jurassic period. The orographic scheme predominantly includes low elevations; tectonic, volcanogenic and erosional forms are quite common. River terraces are distinctly expressed.

The climate of Kazreti, according to general indicators, belongs to steppe type of dry subtropics with moderately cold winters and hot summers. The annual rainfall is on average 500 $550 \mathrm{~mm}$, and the wind speed is $2 \mathrm{~m} \mathrm{sec}^{-1}$ both western and eastern winds are widespread, which change directions during day. During daytime, east and south-east winds prevail, while at night-western. Obviously, this phenomenon facilitates the active transfer of toxic chemical elements with winds in different directions and their subsidence in soils (Avkopashvili et al., 2017).

The following types of soil occur in the study area and adjacent territories: Cinnamonic Soils, Grey Cinnamonic Soils, Brown Forest Soils, Raw Humus Calcareous Soils, Mountain Chernozems and Alluvial Calcareous Soils (Avkopashvili et al., 2019).

In 2014, soil samples were collected from 10 locations. These are Gantiadi, Dmanisi, Balichi, Kazreti, Sakhdrisi, Qveshi, Kvemo Bolnisi, Ratevani, Mtskneti, Nakhiduri (Fig. 1), which are located at different distances from the enterprise. Location 
Gantiadi was selected as check point, which is quite remote and pollution free. Samples were taken at the depths of 0-10 and 30$35 \mathrm{~cm}$ from the surface. The investigated territory was divided into $1000 \times 1000 \mathrm{~m}$ sections, where the samples were taken from 5 points and mixed as a single sample. The samples were dried at $105^{\circ} \mathrm{C}$ for $24 \mathrm{hrs}$, crushed and sieved through a $0.18 \mathrm{~mm}$ sieve. To determine the concentration of metals, $5 \mathrm{ml}$ of $65 \% \mathrm{HNO}_{3}$ was added to $1 \mathrm{~g}$ of soil sample. The flasks were then put on steam $\left(100^{\circ} \mathrm{C}\right)$ for $3 \mathrm{hrs}$ and after $15 \mathrm{~min}$ cooled at room temperature, filtered through Whatman paper $(0.45 \mu \mathrm{m})$ in $50 \mathrm{ml}$ tubes, the volume was made up to $50 \mathrm{ml}$ with distilled water (Avkopashvili et al., 2019). In the prepared solutions, several elements were determined on the ICP-MS (Inductively coupled plasma mass spectrometry) in the laboratory of the University of Georgia, USA. However, in this study distribution of only certain elements such as: Ti, V, Cr, Co, Ni, Cu, Zn, As, Rb, Sr, Mo, Cd, Cs, Ba, Pt, Au, Pb, Thand also B, Na, P, K, Fe were analyzed.

In 2015, soil samples were taken repeatedly from Gantiadi and Kazreti villages in order to compare with the data the data of 2014. The samples were analyzed on the ICP-MS in the laboratory of the University of South Florida, Center for Geochemical Analyzes. The same elements were determined in 2014.

In 2017, soil samples were taken from same 10 villages as in 2014, and $\mathrm{Pb}$ was determined on Atomic Absorption Spectrometer in the laboratory of Elevter Andronikashvili Institute of Physics at Ivane Javakhishvili Tbilisi State University.

\section{Results and Discussion}

The results of this research showed a peculiar distribution of elements in the soil. Balichi is the nearest village from the Abulbukhi mine, the distance from the mine to the village center is $2.5 \mathrm{~km}$. (Fig.1) Table 1 shows the data taken in 2014. Table 3 shows the concentration of elements in the soil Gantiadi and Kazreti villages soil, where samples were collected in 2015, revealed that the certain elements are decreased in comparison to the data, taken in 2014. In 2015, Ti, V, Co, Cu, Zn, Sr and Th concentrations significantly decreased in both Gantiadi and Kazreti villages compared to 2014. The level of $\mathrm{Cr}$, Ni, $\mathrm{Rb}$ and $\mathrm{Cs}$ were reduced only in Kazreti whereas in Gantiadi soil their concentrations were increased. The noted reduction in the level of elements can be explained by the fact that some elements penetrating the soil create molecular complexes with those elements the quantity of which is reduced and migrate together to the depth of the soil. For example, they can create molecules of $\mathrm{BaTiO}_{3}$, VP, etc (Avkopashvili etal., 2019).

In 2015, Ba level significantly increased Gantiadi, as in Kazreti villages in comparison to the 2014 data. This can be explained that in 2014 Sakhdrisi mine opened, whose ore was rich in $\mathrm{Ba}$.

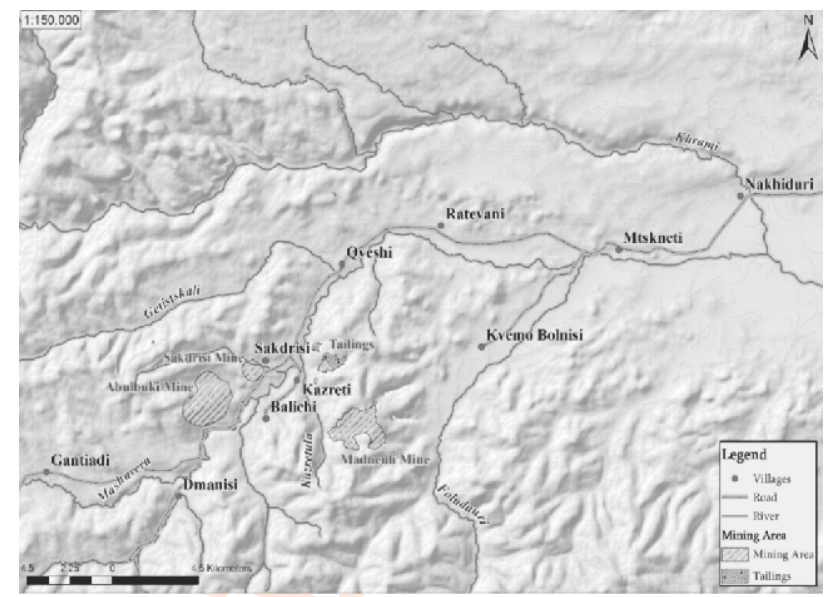

Fig. 1 : Location of the settlements near the mining region where the soil samples were collected

$\mathrm{Cu}, \mathrm{Zn}, \mathrm{Cd}$ and $\mathrm{Pb}$ are toxic elements, however, their concentrations in Gantiadi and Kazreti did not exceed the maximum permissible limits. Though $\mathrm{Cu}, \mathrm{Zn}$, As and $\mathrm{Cd}$ were found to increase in Nakhiduri Table 3 as compared to the permissible limits (Table 2). During the study, the highest level of As was found in Mtskneti soil, compared to other villages (Table 2). Soils in Nakhiduri and Mtskneti villages are irrigated with Mashavera river which is contaminated with heavy metals that causes soil pollution in these villages.

It should also be noted that the amount of $\mathrm{Cd}$ in the soil of Nakhiduri is 10 times higher than in Balichi. This also can be explained the fact that $\mathrm{Cd}$ atomic mass is light and it can be spread over long distances by dust during the wind blowing.

In 2017, soil samples were collected from same villages. The results showed that $\mathrm{Pb}$ was increased in Gantiadi, Dmanisi, Balichi, Kazreti, Sakdrisi and Qveshi villages as compared to 2014 data. As mentioned above, in 2014 Sakdrisi mine was opened and has been intensely active since then. The quarry is close to villages where $\mathrm{Pb}$ level was high as compared to other villages. In addition, $\mathrm{Pb}$ is heavy and when released in the atmosphere gets it accumulated to the nearest places, as reported in Balichi, Sakdrisi and Kazreti villages.

Wide range of data makes it very difficult to visualize distribution of elements on a single graph. Therefore a special formula was developed, where the parameter is introduced that reflects the relative distribution of element in the soil profile:

$$
\delta-\frac{m_{10}-m_{30}}{\left(m_{10}+m_{30}\right) / 2}
$$

In the formula, $m_{10}$ and $m_{30}$ are the concentrations of these elements, respectively, at a depth of 10 and $30 \mathrm{~cm}$ from the surface in $\mathrm{mg} \mathrm{kg}^{-1}$. It is noteworthy that the range of deviation of 
Table 1: Concentration $\left(\mathrm{mg} \mathrm{kg}^{-1}\right)$ of elements present in the soil of study area during 2014

\begin{tabular}{|c|c|c|c|c|c|c|c|c|c|c|}
\hline & Gantiadi & Dmanisi & Balichi & Kazreti & Sakdrisi & Qveshi & $\begin{array}{l}\text { Kvemo } \\
\text { Bolnisi }\end{array}$ & Ratevani & Mtskneti & Nakhiduri \\
\hline B & 8.42 & 9.31 & 18.61 & 16.93 & 25.88 & 14.97 & 18.51 & 18.34 & 18.14 & 9.31 \\
\hline $\mathrm{Na}$ & 523 & 585 & 300 & 312 & 353 & 255 & 247 & 380 & 483 & 344 \\
\hline$P$ & 298 & 250 & 430 & 450 & 2282 & 420 & 272 & 551 & 388 & 288 \\
\hline K & 3700 & 2228 & 8390 & 7261 & 7435 & 6957 & 5021 & 7778 & 6931 & 7216 \\
\hline $\mathrm{Ti}$ & 937.95 & 921.28 & 471.98 & 453.25 & 364.16 & 407.44 & 335.51 & 403.36 & 535.90 & 188.03 \\
\hline V & 83.67 & 104.15 & 53.68 & 65.52 & 34.45 & 64.37 & 53.79 & 65.08 & 64.53 & 46.54 \\
\hline $\mathrm{Cr}$ & 21.42 & 24.13 & 38.75 & 41.10 & 22.01 & 31.66 & 33.26 & 38.56 & 38.78 & 35.41 \\
\hline $\mathrm{Fe}$ & 9500 & 11754 & 8082 & 9550 & 6897 & 10217 & 9119 & 10962 & 9708 & 10597 \\
\hline Co & 15.32 & 18.53 & 12.45 & 13.66 & 9.80 & 14.70 & 14.01 & 13.99 & 15.82 & 17.97 \\
\hline $\mathrm{Ni}$ & 21.10 & 22.21 & 40.48 & 47.24 & 28.48 & 39.72 & 47.40 & 46.56 & 49.67 & 49.97 \\
\hline $\mathrm{Cu}$ & 27.52 & 28.96 & 101.23 & 31.58 & 87.81 & 41.17 & 31.95 & 148.92 & 186.07 & 361.01 \\
\hline $\mathrm{Zn}$ & 83.91 & 70.98 & 93.62 & 65.91 & 120.27 & 113.35 & 54.83 & 155.30 & 233.49 & 348.26 \\
\hline As & 3.56 & 4.59 & 8.61 & 9.26 & 7.94 & 10.19 & 8.90 & 9.89 & 13.18 & 7.33 \\
\hline $\mathrm{Rb}$ & 13.50 & 17.24 & 45.64 & 42.84 & 28.81 & 33.51 & 27.53 & 36.77 & 36.15 & 39.56 \\
\hline $\mathrm{Sr}$ & 91.94 & 105.07 & 98.46 & 215.80 & 232.79 & 144.91 & 123.08 & 113.11 & 159.73 & 113.56 \\
\hline $\mathrm{Cd}$ & 0.16 & 0.14 & 0.22 & 0.17 & 0.28 & 0.34 & 0.17 & 0.63 & 1.44 & 2.34 \\
\hline Cs & 0.77 & 1.19 & 2.60 & 2.83 & 1.44 & 1.86 & 1.81 & 2.25 & 2.20 & 1.97 \\
\hline $\mathrm{Ba}$ & 98.0 & 104.9 & 220.3 & 233.7 & 487.8 & 201.5 & 136.0 & 170.6 & 168.6 & 171.4 \\
\hline $\mathrm{Au}$ & 0.04 & 0.02 & 0.01 & 0.03 & 0.04 & 0.01 & 0.04 & 0.05 & 0.07 & 0.03 \\
\hline $\mathrm{Pb}$ & 10.44 & 10.13 & 18.73 & 16.23 & 16.59 & 21.74 & 15.81 & 20.00 & 17.18 & 19.59 \\
\hline Th & 6.57 & 7.38 & 15.10 & 16.98 & 9.04 & 13.41 & 13.29 & 13.04 & 13.76 & 14.66 \\
\hline
\end{tabular}

Table 2 : Maximum permissible limits for heavy metals $\left(\mathrm{mg} \mathrm{kg}^{-1}\right)$ in agricultural soil (Georgian standards)

\begin{tabular}{llllll}
\hline Metals & $\mathrm{Cu}$ & $\mathrm{Zn}$ & $\mathrm{Pb}$ & $\mathrm{Cd}$ & As \\
\hline Limits & 132 & 300 & 32 & 2 & 2 \\
\hline
\end{tabular}

Table 3 : Concentrations of chemical elements in soils at the surface of 0-10 and 30-35 cm in soil profiles (Gantiadi and Kazreti villages, 2014-2015 years)

\begin{tabular}{|c|c|c|c|c|c|c|c|c|}
\hline & \multicolumn{2}{|c|}{ Gantiadi, 2014} & \multicolumn{2}{|c|}{ Gantiadi, 2015} & \multicolumn{2}{|c|}{ Kazreti, 2014} & \multicolumn{2}{|c|}{ Kazreti, 2015} \\
\hline & $10 \mathrm{~cm}$ & $30 \mathrm{~cm}$ & $10 \mathrm{~cm}$ & $30 \mathrm{~cm}$ & $10 \mathrm{~cm}$ & $30 \mathrm{~cm}$ & $10 \mathrm{~cm}$ & $30 \mathrm{~cm}$ \\
\hline $\mathrm{Ti}$ & 920.53 & 1016.49 & 258.022 & 239.399 & 530.04 & 376.47 & 178.814 & 216.228 \\
\hline V & 79.48 & 82.09 & 34.522 & 35.949 & 67.59 & 63.44 & 35.107 & 38.257 \\
\hline $\mathrm{Cr}$ & 24.36 & 19.3 & 24.939 & 27.225 & 42.33 & 39.87 & 25.298 & 26.837 \\
\hline Co & 15.49 & 15.4 & 7.435 & 7.653 & 14.19 & 13.14 & 7.347 & 7.335 \\
\hline $\mathrm{Ni}$ & 21.71 & 17.79 & 26.38 & 27.27 & 49.46 & 45.01 & 25.9 & 25.858 \\
\hline $\mathrm{Cu}$ & 28.37 & 24.5 & 13.423 & 13.598 & 32.77 & 30.39 & 14.659 & 13.899 \\
\hline $\mathrm{Zn}$ & 86.33 & 76.17 & 33.84 & 33.417 & 66.85 & 64.97 & 32.148 & 31.983 \\
\hline As & 3.58 & 3.36 & 5.668 & 6.129 & 9.75 & 8.76 & 7.052 & 6.792 \\
\hline $\mathrm{Rb}$ & 13 & 15.15 & 29.056 & 32.718 & 45.31 & 40.37 & 22.923 & 25.72 \\
\hline $\mathrm{Sr}$ & 95.85 & 95.88 & 69.275 & 72.794 & 234 & 197.6 & 149.637 & 161.838 \\
\hline Mo & 0.31 & 0.22 & 0.322 & 0.206 & 0.51 & 0.41 & 0.421 & 0.409 \\
\hline $\mathrm{Cd}$ & 0.16 & 0.14 & 0.195 & 0.208 & 0.18 & 0.17 & 0.198 & 0.196 \\
\hline Cs & 0.73 & 0.84 & 1.501 & 1.639 & 2.89 & 2.76 & 1.309 & 1.438 \\
\hline $\mathrm{Ba}$ & 101 & 90.8 & 346.727 & 364.256 & 235.6 & 231.9 & 391.202 & 340.804 \\
\hline $\mathrm{Au}$ & 0.04 & 0.06 & 0.028 & 0.031 & 0.05 & 0.02 & 0.037 & 0.04 \\
\hline $\mathrm{Pb}$ & 11.21 & 9.13 & 8.108 & - & 18.08 & 14.37 & - & - \\
\hline Th & 6.49 & 6.48 & 3.326 & 3.499 & 17.07 & 16.88 & 3.033 & 3.097 \\
\hline
\end{tabular}


this parameter for any metal is the interval $(-2 ; 2) ;-2<\delta<2$. Fig. 4 shows how this parameter varies for different elements in the villages of Balichi and Nakhiduri.

The change in this parameter over time also depends on the type of soil contamination. Table 4 gives the distribution of Cadmium at different periods in Balichi and Ratevani at a depth of 10 and $30 \mathrm{~cm}$ from the soil surface, respectively.
Fig. 4 shows the curves of dependence of parameter of the relative distribution of cadmium in depth $(\delta)$ on the time for the soils of Balichi and Ratevani villages. The graph clearly shows that these curves differed significantly from each other.

Soil types were different in the villages of Nakhiduri and Mtskneti and despite the fact that they were quite close to each other, the elements distribution varied significantly. This is clearly

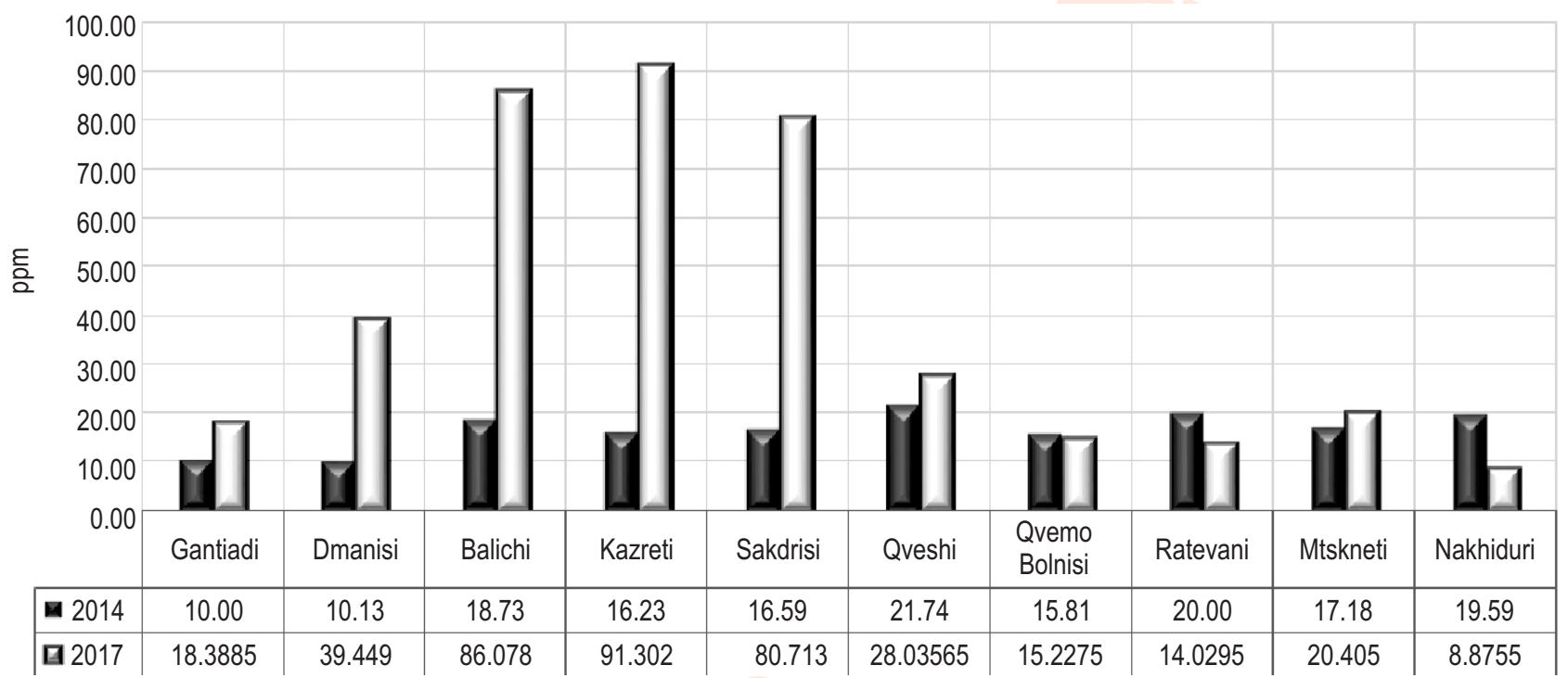

Fig. 2 : Pb concentration (ppm) in villages, 2014 and 2017 data comparison.

2.00

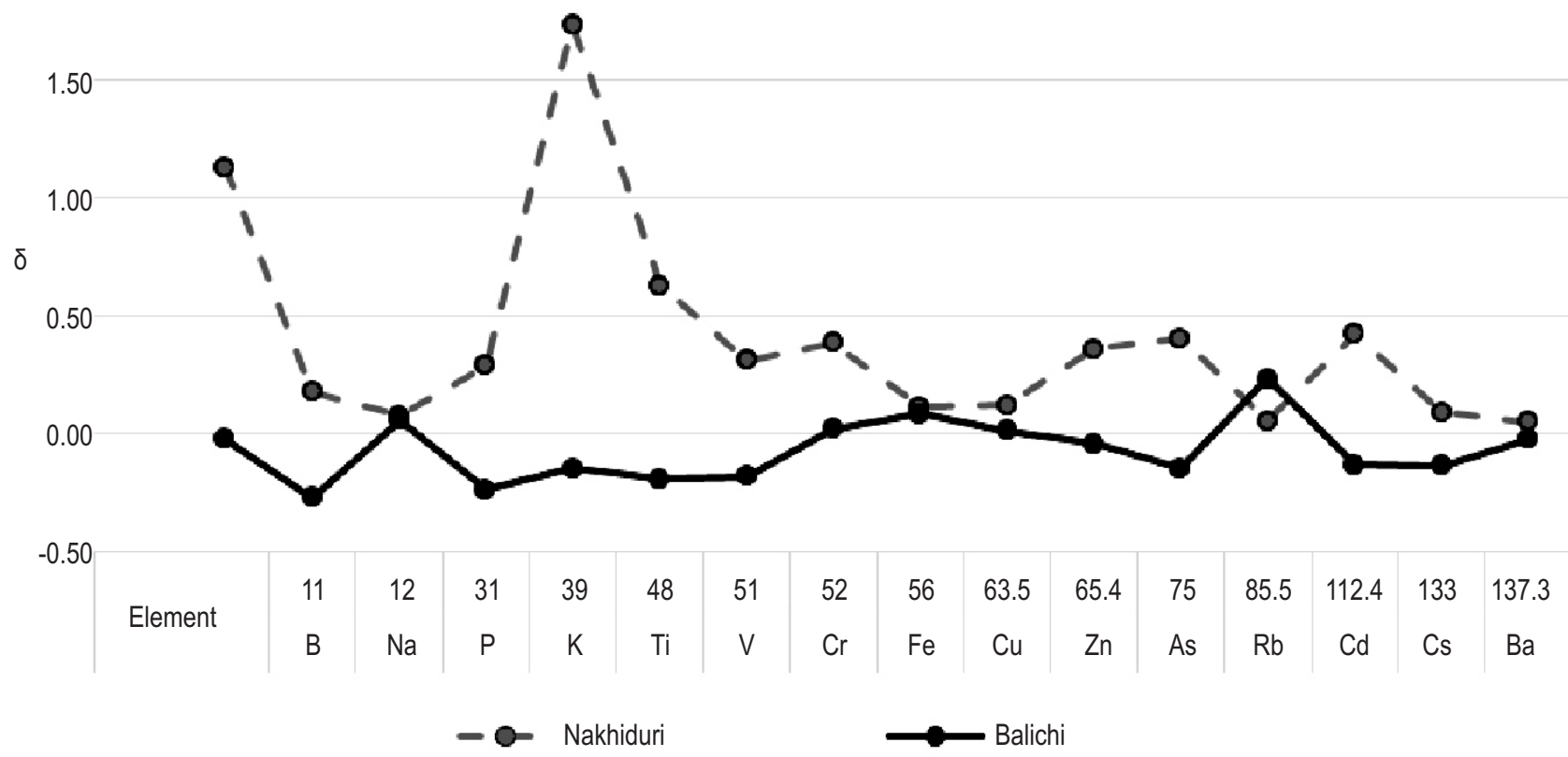

Fig. 3 : Numerical values of parameter of relative distribution of chemical elements in soils (On the horizontal axis there are chemical elements, the points correspond to the numerical values of the parameter of the relative distribution of these elements according to depth). 
Table 4 : Numerical values of cadmium concentration $\left(\mathrm{mg} \mathrm{kg}^{-1}\right)$ in different periods of 2012 in the villages of Balichi and Ratevani at a depth of $0-10$ and $30-35 \mathrm{~cm}$ from the soil

\begin{tabular}{llll}
\hline Date & Depth $(\mathbf{c m})$ & \multicolumn{2}{c}{ Settlements } \\
\cline { 3 - 4 } & & Balichi & Ratevani \\
\hline 17.07 .2012 & 10 & 0.73 & 2.13 \\
23.08 .2012 & 30 & 1.32 & 1.84 \\
& 10 & 2.65 & 3.2 \\
27.10 .2012 & 30 & 2.85 & 3.7 \\
& 10 & 2.82 & 3.17 \\
\hline
\end{tabular}

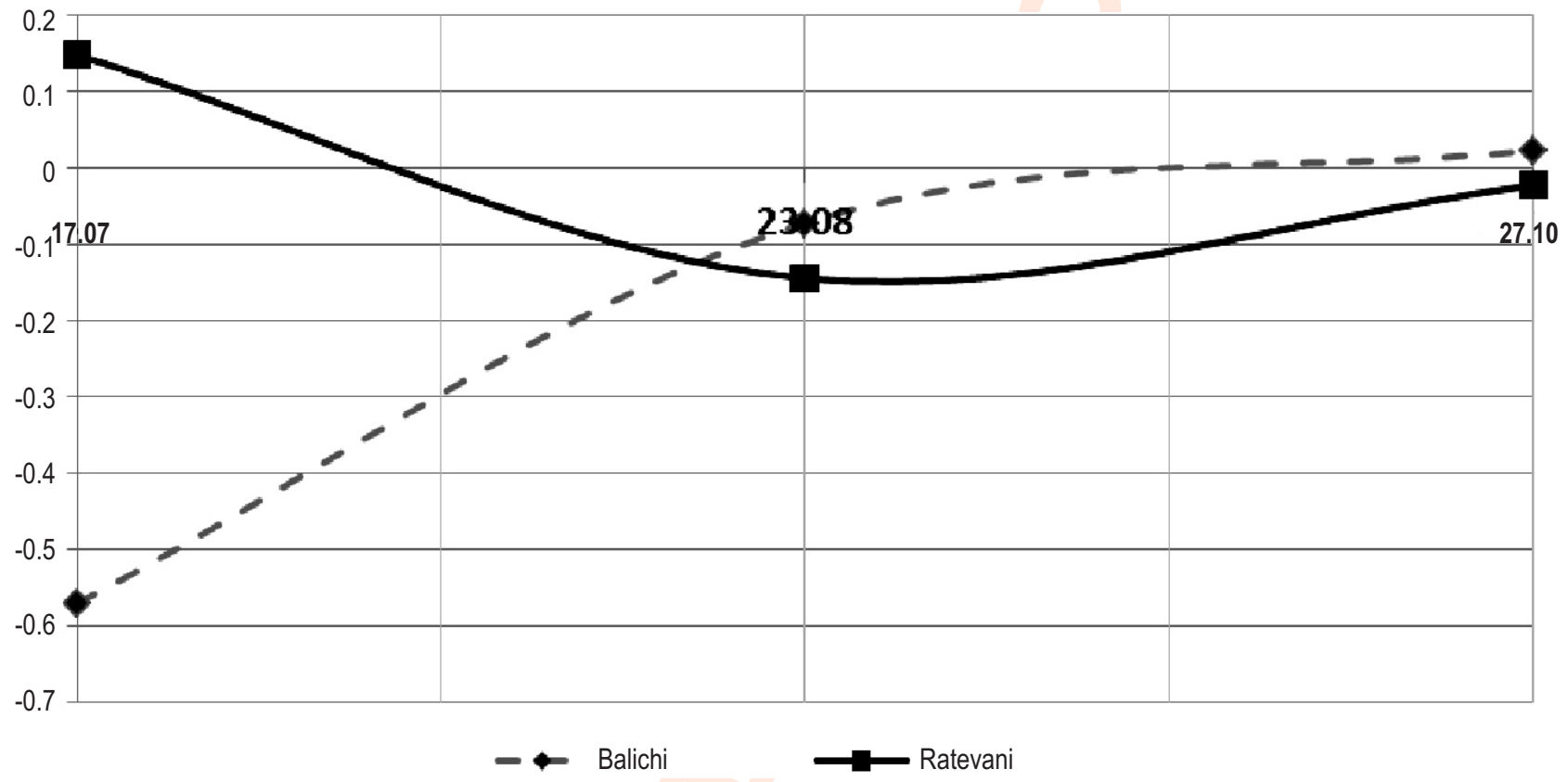

Fig. 4 : The curves of dependence of parameter of relative cadmium distribution on depth $(\delta)$ on time (on the horizontal axis, the time in days is given, on the vertical axis - numerical values of the parameter of relative distribution of chemical elements in soil profile).

seen from Table 1 where the numerical values of the concentration of some metals in soils are presented.

The concentration of lighter metals $\mathrm{B}, \mathrm{Na}, \mathrm{P}$ and $\mathrm{Ti}$ in soil of Mtskneti was higher than Nakhiduri whereas the concentration of $\mathrm{Cu}, \mathrm{Zn}, \mathrm{Rb}$ and $\mathrm{Cd}$ was more in the soil of Nakhiduri.

Fig. 5 shows the numerical values of parameter of relative distribution of chemical elements in depth in the soils of Nakhiduri and Mtskneti villages (also known as Kiristcekhi).

Obviously, in this case, different distribution of metals in the soil profile is determined by the difference in environmental conditions and type of soils.

Observations showed that for last 5 years, the properties of investigated soils in Nakhiduri and Mtskneti villages have deteriorated sharply. In particular, in Mtskneti the soil surface was sometimes covered with a waterproof whitish-green gypsum film, this caused reduction of porosity, $\mathrm{pH}$ change, and soil fertility loss of. As it turned out, limestone is poured into the waste water of the plant, in order to neutralize the acidity, and to drain the water in the collector. In this case, the gypsum formed with river water falls into the irrigation system, by which the agricultural land is irrigated. Over time, gypsum accumulates on the surface of the soil and covers as a thin film, which in turn worsens their aeration and filtration capacity, and also causes a sharp decline in fertility. This process causes compaction of soil, leading to unfavorable hydrophysical conditions for plants. The data of water capacity of soils varied between $19.0-82.6 \%$, and the amount of productive moisture was rather low (6.0-20.6\%).

Soil contamination is directly related to their agrophysical conditions. In heavily contaminated soils, the cementation process occurs, as a result of which the bulk density of soils rises 


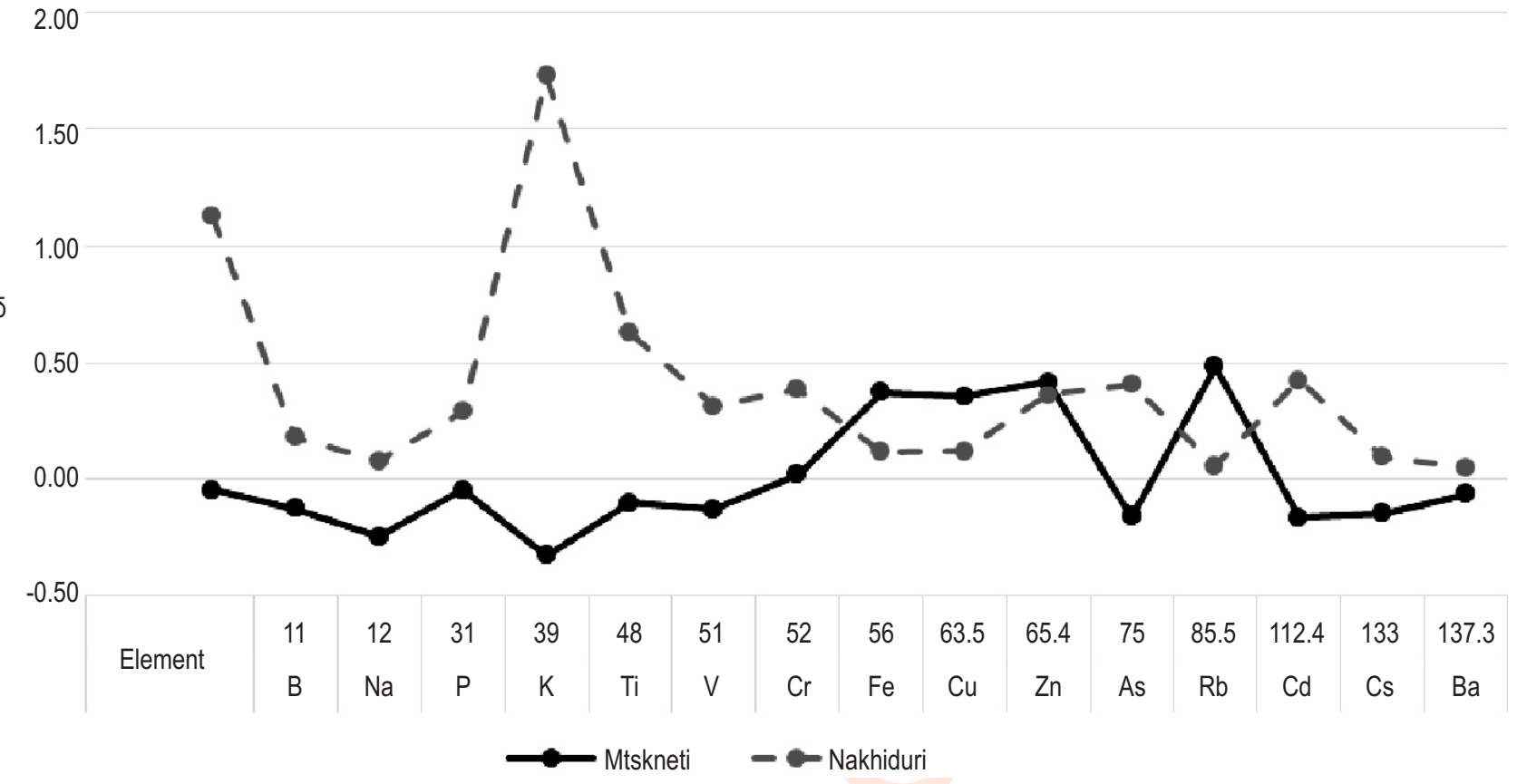

Fig. 5 : Numerical values of the parameter of relative distribution of chemical elements in the soil profile (on the horizontal axis, there are chemical elements, and above them points corresponding to the numerical values of the parameter of relative distribution of these elements in soil profile are given).

sharply, the total porosity decreases, and the water permeability reaches a critical limit.

The logical result of unfavorable parameters of agrophysical properties of the studied soils is a sharp deterioration in their filtration capacity. In brown soils, water percolates only $46 \mathrm{~cm}$ per day, creating conditions that are not optimal for plants.

Thus, the research revealed that in Kvemo Kartli region some heavy metals were reported to exceed the permissible limits due to intensive gold and copper mining. The three year ongoing project confirmed that soil pollution by certain heavy metals is gradually increasing from year to year. Contamination reaches to the long distances that is promoted on the one hand by the wind and on the other by using polluted river water for the irrigation purposes. The results of analysis also figured out that some of elements are significantly reduced compared with the previous year, which can be explained by the fact that elements infiltrating the soil create a molecular compound with the elements, which are reduced, and they migrate together in the soil profile. The study showed that amount of certain elements are higher in the villages located to far distances from the mine and have higher altitude, this factor can be described that by the wind the elements with lighter atomic mass are migrating toward these villages and through the rainfall they are being accumulated in the soil.

\section{Acknowledgment}

The authors express their deepest gratitude to Professor Garry Mill, with financial support whom it became possible to identify chemical elements in the soil samples from the University of Georgia (USA).

\section{References}

Alkorta, I., J.H. Allica, J.M. Becerril, I. Amezaga, I. Albizu and C. Gabisu: Recent findings on the phytoremediation of soils contaminated with environmentally toxic heavy metals and metalloids such as zinc, cadmium, lead and arsenic. Rev. Environ. Sci. Bio., 3, 71-90 (2004).

Avkopashvili, G., M. Avkopashvili, A. Gongadze and R. Gakhokidze: Eco-monitoring of Georgia's contaminated soil and water with heavy metals, Carpath. J. Earth Env., 12, 595-604 (2017).

Avkopashvili, G., M. Avkopashvili, A. Gongadze, M. Tsulukidze and E. Shengelia: Determination of $\mathrm{Cu}, \mathrm{Zn}$ and $\mathrm{Cd}$ in soil, water and food products in the vicinity of RMG gold and gopper mine, Kazreti, Georgia. Ann. Agrar. Sci., 15, 269-272 (2017).

Avkopashvili, G., M. Avkopashvili, I. Avkopashvili, K. Kazaishvi and N. Tsikaridze: Monitoring of cadmium contaminated soil in Kvemo Kartli region (Republic of Georgia). Open J. Geol., 9, 187-192 (2019).

Bargali, K., V. Manral, K. Padalia, S. Bargali and V. Upadhyay: Effect of vegetation type and season on microbial biomass carbon in Central Himalayan forest soils, India. Catena, 171, 125-135 (2018). 
Bargali, S., K. Padalia and K. Bargali: Effects of tree fostering on soil health and microbial biomass under different land use systems in Central Himalaya. Land Degrad. Dev., 30, 1-15 (2019).

Baycu, G., D. Tolunay, H. Ozden, I. Csatari, S. Karadag, T. Agba and S.E. Rognes: An abandoned copper mining site in Cyprus and assessment of metal concentrations in plants and soil. Int. J. Phytoremediat., 17, 622-631 (2015).

Conesa, M.H., A.M. Faz and R. Arnaldos: Heavy metal accumulation and tolerance in plants from mine tailings of the semiarid Cartagena-La Union mining district (SE Spain). Sci. Total Environ., 366, 1-11 (2006).

D'Amore, J.J., S.R. Al-Abed, K.G. Scheckel and J.A. Ryan: Methods for speciation of metals in soils: A review. J. Environ. Qual., 34, 17071745 (2005).

Dixit, R., Wasiullah, D. Malaviya, K. Pandiyan, U. B. Singh, A. Sahu, R. Shukla, B.P. Singh, J.P. Rai, P.K. Sharma, H. Lade and D. Paul: Bioremediation of heavy metals from soil and aquatic environment: An overview of principles and criteria of fundamental processes. Sustainability, 7, 2189-2212 (2015).

Dragovića, S., N. Mihailovića and B. Gajićb: Heavy metals in soils: Distribution, relationship with soil characteristics and radionuclides and multivariate assessment of contamination sources. Chemosphere, 72, 491-495 (2008).

Felix-Henningsen, P., T. Urushadze, E. Narimanidze, I. Wichmann, D. Steffens and B. Kalandadze: Heavy metal pollution of soils and food crops due to mining wastes in the Mashavera River Valley. Bull. Georgian Natl.Acad. Sci., 175, 97-106 (2007).

Finžgar, N., B. Kos and D. Leštan: Bioavailability and mobility of Pb after soil treatment with different remediation method. Plant Soil Environ., 52, 25-34 (2006).

Giller Ken, E., E. Witter and P. Mcgrath: Toxicity of heavy metals to microorganisms and microbial processes in agricultural soils: $\mathrm{A}$ review. Soil Biol. Biochem., Elsevier, 30, 1389-1414 (1998).

Helmisaari, H.S., M. Salemaa, J. Derome, O. Kiikkilä, C. Uhlig and T.M. Nieminen: Remediation of heavy metal-contaminated forest soil using recycled organic matter and native woody plants. J. Environ. Qual., 36, 1145-153 (2007).

Kabata-Pendias, A. and H. Pendias: Trace Metals in Soils and Plants. $2^{\text {nd }}$ Edn., CRC Press, Boca Raton, Fla, USA(2001).
Khatisashvili, G., L. Matchavariani and R. Gakhokidze: Improving phytoremediation of soil polluted with hydrocarbons in Georgia. In: Soil Remediation and Plants: Prospects and Challenges (Eds.: K.R. Hakeem, M. Sabir, M. Ozturk and A.R. Mermut). Elsevier, Amsterdam-Boston-Heidelberg-London-New-Y ork-Oxford-ParisSan Diego-San Francisco-Singapore-Sydney-Tokyo, pp. 547-569 (2015).

Khan, S., Q. Cao, Y.M. Zheng, Y.Z. Huang and Y.G. Zhu: Health risks of heavy metals in contaminated soils and food crops irrigated with wastewater in Beijing, China. Environ. Poll., Elsevier, 152, 686-692 (2008).

Matchavariani, L. and B. Kalandadze: Pollution of soils by heavy metals from irrigation near mining region of Georgia. Forum Geografic, 11, 127-136 (2012).

Matchavariani, L., B. Kalandadze, L. Lagidze, N. Gokhelashvili, N. Sulkhanishvili, N., Paichadze and G. Dvalashvili: Soil quality changes in response to their pollution by heavy metals. Georgia. J. Environ. Biol., 36, 85-90 (2014).

Placek, A., A. Grobelak and M. Kacprzak: Improving the phytoremediation of heavy metals contaminated soil by use of sewage sludges, Int. J. Phytoremediat., 18, 605-618 (2016).

Prasad, M.N.V. and H. Freitas: Metal hyper accumulation in plants 5 Biodiversity prospecting for phytoremediation technology. Electron. J. Biotechn., 6, 275-321 (2003).

Prasad, M.N.V.: Trace elements as contaminants and nutrients, consequences in ecosystem and human health. John Wiley Sons, New York, Tokyo, pp. 777 (2008).

Sherameti, I. and A. Varma: Soil Heavy Metals (Sherameti, Irena, Varma, Ajit (Eds.). Soil Biology, Springer, 478 (2010).

Withanachchi, S.S., G. Ghambashidze, I. Kunchulia, T. Urushadze. and A. Ploeger: Water quality in surface water: A preliminary assessment of heavy metal contamination of the Mashavera River, Georgia. Int. J. Environ. Res. Public Hlth., 15, 1-25 (2018).

World Reference Base for Soil Resources. International Soil Classification System for Naming Soils and Creating Legends for Soils Maps, FAO UN, 106, Rome, 2015, 192 (2014).

Zhang, M.K., Z.Y. Liu and H. Wang: Use of single extraction methods to predict bioavailability of heavy metals in polluted soils to rice. Commun. Soil Sci. Plan., 41, 820-831 (2010). 